Цьоменко Аліна Володимирівна, помічник адвоката АО «Новіков та партенри», м. Київ, вул. Мельникова,12, моб. тел. +380631035399, e-mail: alina.tsmnk@gmail.com, https//orcid.org/0000-0002-5615-7838.

\title{
ОСОБЛИВОСТІ РОЗГЛЯДУ АДМІНІСТРАТИВНИХ СПРАВ ПРО ОСКАРЖЕННЯ ПІДЗАКОННИХ НОРМАТИВНО-ПРАВОВИХ АКТІВ
}

\begin{abstract}
Анотація. Стаття присвячена комплексному дослідженню питань особливості розгляду і вирішення адміністративних справ про оскарження підзаконних нормативно-правових актів. У статті досліджено поняття підзаконних нормативно-правових актів, справи щодо оскарження котрих підсудні адміністративним судам та наголошено на процесуально-правових особливостях провадження у справах щодо оскарження підзаконних нормативноправових актів.
\end{abstract}

Наголошено, що важливий практичний та науково-теоретичний інтерес становлять питання наслідків визнання підзаконного нормативно-правового акту протиправним та нечинним. Підкреслено проблематику питання застосування інституту забезпечення позову у справах щодо оскарження підзаконних нормативно-правових актів. Наголошено, що адміністративні суди мають певну свободу вибору в прийнятті рішення про необхідність забезпечення позову. Проте така свобода обмежена як загальними вимогами, що висуваються процесуальним законодавством до розгляду адміністративних справ та вимогами до судових рішень, так і спеціальними, що стосуються виключно інституту забезпечення позову. Підкреслено, що виникає необхідність вирішення питання, яким чином забезпечити позов, тобто зупинити дію нормативно-правового акту, якщо суду необхідно оцінити протиправність (встановити наявність цих «очевидних ознак»), а це по суті можна зробити лише у рішенні по справі. Відповідно, суд не може оголосити свою правову позицію до винесення рішення у справі, демонструючи ставлення до питання забезпечення позову.

У роботі сформульовані пропозиції щодо удосконалення процесу доказування у справах щодо оскарження підзаконних нормативно-правових актів.

3 метою ефективної реалізації забезпечення позову запропоновано здійснювати не зупинення дії підзаконного нормативно-правового акту в цілому, а лише у конкретних правовідносинах щодо особи, яка звернулася за захистом своїх інтересів шляхом оскарження нормативно-правового акту.

Ключові слова: підзаконний нормативно-правовий акт, адміністративне судочинство, позовне провадження, забезпечення позову, протиправний акт, нечинний акт. 
Tsomenko Alina Volodymyrivna, Assistant Lawyer, Novikov \& Partners JSC, Kyiv, str. Melnikova, 12, mobile phone +380631035399, e-mail: alina.tsmnk@gmail.com, https // orcid. org / 0000-0002-5615-7838.

\section{FEATURES OF CONSIDERATION AND RESOLUTION OF ADMINISTRATIVE CASES ON APPEAL OF BY-LAWS}

Abstract. The paper is devoted to a comprehensive study of the specifics of consideration and resolution of administrative cases on appeal of by-laws. The paper examines the concept and types of by-laws, cases on appeal of which are within the jurisdiction of administrative courts, and emphasizes the procedural and legal features of proceedings on cases on appeal of by-laws.

It is noted that the issue of consequences of recognizing a by-law as illegal and invalid is of important practical and scientific-theoretical interest. The issue of applying the institution of securing a claim in cases of appeal against by-laws is emphasized. It is noted that administrative courts have a certain freedom of choice in making a decision on the need to secure a claim. However, such freedom is limited both by the general requirements put forward by the procedural legislation for the consideration of administrative cases and requirements for court decisions, and by special requirements that relate exclusively to the institution of securing a claim.

There is outlined, that necessity to resolve a problem of providing of secure the claim appears. Namely, how to stop the action of regulatory act where the court has to estimate illegality (establish the presence of these "obvious signs") whereas it can be done only in the decision on the case. As the result, the court cannot to proclaim its legal position before the decision on the case demonstrating the attitude to the issue of securing the claim.

The paper formulates suggestions for improving the process of proof in cases of appeal against regulatory act.

In order to effectively implement the security of the claim, it is proposed not to suspend the bylaw in general, but only in specific legal relations with respect to a person who has applied for protection of their interests by appealing the legal act.

Keywords: regulatory act, administrative proceedings, claim proceedings, securing a claim, illegal act, invalid act.

Постановка проблеми. Сучасний етап розвитку української державності та суспільства відзначається тривалим реформуванням багатьох сфер життєдіяльності державного організму. У цих процесах надзвичайно важливе місце посідає проведення реформи адміністративного судочинства. Останнє десятиліття демонструє значне зростання ролі судового контролю за нормативнопроектувальною діяльністю органів та посадових осіб державного управління та місцевого самоврядування. Потреба у здійсненні такого контролю стала вкрай актуальною після конституційно-правового закріплення євроатлантичного курсу України, з яким пов'язане прийняття державою ряду зобов'язань, в тому числі - у правовій сфері. 
Головною метою реформи правової системи $є$ найповніше забезпечення конституційних засад організації державної влади, принципу верховенства права, гуманістичних вимог щодо діяльності держави. У вирішені цих завдань велике значення мають різні галузі права, але вирішальну роль повинні відігравати такі фундаментальні галузі публічного права, як конституційне та адміністративне право. Визнання Україною найважливіших міжнародних стандартів у галузі захисту прав людини потребує відповідного юридичного механізму забезпечення захисту прав і свобод громадян, юридичних осіб, що обумовлює актуальність проблеми утворення в Україні адміністративної юстиції.

Час засвідчив недостатню ефективність чинних в Україні органів і процедур вирішення правових спорів, де однією стороною виступає громадянин (або юридична особа), а іншою - орган виконавчої влади або орган місцевого самоврядування. Не $є$ повною система захисту прав громадян в Україні і з точки зору іiі відповідності світовим та європейським стандартам. Одна з причин такого становища, як уявляється, полягає в тому, що законодавство про оскарження в судовому порядку рішень і діяльності органів управління, посадових осіб, які порушують права і свободи громадян і юридичних осіб тривалий час з зрозумілих історичних причин відносило справи даної категорії до підсудності судів загальної юрисдикції.

Судовий контроль у сфері діяльності виконавчої влади і органів місцевого самоврядування в Україні, як видається, був досить обмеженим, і це при тому, що порушення органами публічної влади прав і свобод громадян допускаються досить часто. Розвиток сучасного суспільства також обумовив збільшення кількості звернень до судових органів як громадян, так і юридичних осіб. Це визначається процесами становлення ринкової економіки, ускладненням соціально-економічних зав'язків та багатьма іншими факторами.

Аналіз останніх досліджень i публікацій. Питання оскарження нормативно-правових актів у порядку адміністративного судочинства були предметом дослідження таких авторів: О. Духневича, Є. Гетьмана, Л. Горбунова, В. Зуя, А. Сзерова, В. Кабанова, Д. Монастирського, Я. Рябченко, І. Тимченко, С. Шевчука, Н. Янюк та ін.

Із позицій науково-теоретичного аналізу питання оскарження нормативноправових актів у порядку адміністративного судочинства залишається малодослідженою сферою. До числа найбільш вагомих наукових досліджень можна віднести праці таких вчених: Ю. Педько «Становлення та правове регулювання адміністративної юстиції в України» (2004р.) [1]; I Грибок «Оскарження рішень органів виконавчої влади в адміністративному порядку» (2006 р.) [2]; П. Вовка «Захист прав, свобод та інтересів громадян в адміністративному суді першої інстанції» (2009р.) [3]; Т. Калиновської «Нормативно-правові акти місцевих рад як органів місцевого самоврядування в Україні» (2011) [4]; Я. Рябченко «Оскарження нормативно-правових актів в адміністративному судочинстві» (2011р.) [5].

Проблематика оскарження нормативно-правових актів у адміністративному судочинстві, у тому числі і актів підзаконного характеру, незважаючи на свою виняткову актуальність, залишається мало дослідженою. Особливо прикро, що 
після змін у законодавстві 2017 року оцінка проблемним питанням дається лише в окремих публікаціях і не знаходить свого відображення на рівні дисертаційних досліджень.

Метою статті є дослідження питання особливостей розгляду і вирішення адміністративних справ про оскарження підзаконних нормативно-правових актів.

Виклад основного матеріалу. Відомо, що адміністративний процес складне явище, системний характер якого обумовлюється значним обсягом предметної регламентації, що охоплює найрізноманітніші сфери діяльності публічної адміністрації та численні категорії індивідуальних справ [6].

Оскарження підзаконних нормативно-правових актів у структурі адміністративного судочинства $є$ особливим видом позовного провадження в окремих категоріях адміністративних справ. У першу чергу, це втілено у наслідках визнання нормативно-правового акту протиправним та нечинним.

Підкреслимо, що провадження у справах щодо оскарження підзаконних нормативно-правових актів віднесено до складних категорій справ. В цілому, юридичні справи можна класифікувати на прості (easy cases) та складні (hard cases). Як зазначає С. Шевчук, легка справа передбачає одну відповідь на існуючу правову проблему, тоді, як «складна справа виникає у випадку, коли правова проблема може мати декілька різних рішень, й суддя повинен у процесі здійснення правосуддя зайняти певну позицію, тобто здійснити дискрецію або вибір порядку аргументації» [7].

Н. Блажівська зазначає, що оскарження нормативно-правових актів є однією 3 найважливіших категорій справ, які підлягають розгляду в адміністративних судах, що обумовлено «надзвичайно великим ступенем впливу результатів розгляду судом таких справ на систему правового регулювання та суспільство в цілому» та, відповідно, мають «підвищений соціальний ефект» [8].

Я. Рябченко вважає, що «зазначена процедура є дуже важливою для правової держави, де кожен громадянин спроможний самостійно законними засобами реагувати на порушення своїх прав і свобод. Така процедура реалізується через функціонування адміністративних судів й спрямована на вдосконалення правотворчої діяльності суб’єктів владних повноважень» [5].

Велике значення надається можливості оскарження підзаконних нормативно-правових актів органів виконавчої влади саме в судовому порядку, оскільки лише в цьому випадку ініціатива оскарження належить фізичним та юридичним особам, права та законні інтереси яких порушуються в процесі реалізації, застосування конкретного нормативно-правового акту [9].

Аналіз положень законодавства доводить, що діяльність адміністративного суду щодо перевірки нормативно-правових актів щодо відповідності їх Конституції та законам України необхідно розглядати одночасно і як гарантію забезпечення законності у державі в цілому, та як особливий різновид провадження у процесі розгляду адміністративних справ. Окремо зауважимо, що така діяльність контрольного характеру носить безумовно конфліктний правовий характер (у науці адміністративного процесу адміністративні провадження пропонують об'єднати за наявністю або відсутністю у них спору про право у дві групи: конфліктні та неконфліктні) [10]. 
Із нормативно-правових позицій, ст. 5 КАС України «Право на звернення до суду та способи судового захисту» вказує, що «кожна особа має право в порядку, встановленому цим Кодексом, звернутися до адміністративного суду, якщо вважає, що рішенням, дією чи бездіяльністю суб'єкта владних повноважень порушені їі права, свободи або законні інтереси, і просити про їх захист шляхом: 1) визнання протиправним та нечинним нормативно-правового акта чи окремих його положень» [10].

Практичною реалізацією цього права $\epsilon$ застосування правил загального позовного провадження, котрі застосовують при розгляді справ у спорах «щодо оскарження нормативно-правових актів, за винятком випадків, визначених цим Кодексом» (п. 1, ч. 4 ст. 12 «Форми адміністративного судочинства») [10].

Таким чином, оскарження підзаконних нормативно-правових актів у структурі адміністративного судочинства необхідно розглядати одночасно і як гарантію забезпечення законності у державі в цілому, та як особливий різновид провадження у процесі розгляду адміністративних справ. При цьому варто пам'ятати, що діяльність із перевірки нормативно-правових актів на відповідність їх до Конституції та законів України є не лише окремим видом провадження у процесі здійснення адміністративного судочинства, а обов'язковим елементом розгляду практично кожного адміністративного спору. Тобто, така діяльність $\epsilon$ окремою процедурою адміністративного процесу в цілому.

Предметом оскарження в адміністративний суд можуть бути нормативноправові акти й рішення, в тому числі нормативні акти органів виконавчої влади, органів місцевого самоврядування, а також дії або бездіяльність цих органів, які, на думку фізичних осіб чи інших суб'єктів публічно-правових відносин, порушують або обмежують права та свободи людини і громадянина.

Діяльність із перевірки нормативно-правових актів на відповідність їх до Конституції та законів України є не лише окремим видом провадження у процесі здійснення адміністративного судочинства, а обов'язковим елементом розгляду практично кожного адміністративного спору. Тобто, така діяльність є окремою процедурою адміністративного процесу в цілому.

Підзаконні нормативно-правові акти - це акти, що приймаються уповноваженими на це суб’єктами правотворчості на основі i на виконання законів і не суперечать їм. У контексті тематики нашого дослідження ми можемо запропонувати власне визначення підзаконного нормативно-правового акту: нормативно-правовий акт, що приймається на виконання та конкретизацію приписів закону за умови відсутності протиріч та відсутності «нових» приписів, які змінюють правову спрямованість законодавчого нормативно-правового акту. Підзаконний нормативно-правовий акт застосовується неодноразово, діє протягом тривалого часу, а правозастосовчий акт - тільки при вирішенні певної юридичної справи, тобто в конкретному випадку.

Якщо нормативні правові акти містять в собі загальні приписи у вигляді норм права і розраховані на багаторазове застосування, то акти застосування норм права містять приписи індивідуального характеру. Нормативно-правові акти адресовані невизначеному колу осіб, у той час як акти застосування норм права - конкретним, персонально визначеним особам, i виділяються 3 певного 
приводу.

Складним процесуальним аспектом у процесі вирішення зазначеної категорії справ є застосування інституту забезпечення позову у цій категорії справ. Як відомо, інститут забезпечувальних заходів - класичний інститут судового процесу, що бере свій початок ще з часів римського права. Його метою є вжиття заходів щодо охорони матеріально-правових інтересів позивача від можливих недобросовісних дій з боку відповідача. Тим самим створюються передумови для реального та ефективного виконання судового рішення у разі задоволення позовних вимог, у тому числі задля запобігання потенційним труднощам під час подальшого його виконання.

Правова природа особливостей забезпечення позову в адміністративному процесі випливає із суб'єктного складу його учасників та юрисдикційної компетенції адмінсудів, що поширюється на вирішення спорів у сфері публічноправових відносин. Це зумовлює відмінні від інших процесів види забезпечення позову, особливості доказування необхідності вжиття таких заходів та засоби обгрунтування заяв про забезпечення позову [11].

Так, інститут забезпечення адміністративного позову регламентовано главою 10 (ст.151-158) Кодексу адміністративного судочинства України [10]. Суд за заявою учасника або з власної ініціативи має право вжити чітко визначені законодавством заходи забезпечення позову; при цьому вони повинні бути в межах позовних вимог. Важливо, що забезпечення позову допускається як до пред’явлення позову, так і на будь-якій стадії розгляду справи.

Підстави для забезпечення позову: невжиття таких заходів може вплинути на виконання рішення суду чи ефективний захист або поновлення порушених чи оспорюваних прав/інтересів позивача; наявні очевидні ознаки протиправності рішення, дії чи бездіяльності суб'єкта владних повноважень та порушення таким рішенням прав, свобод або інтересів позивача. Позов може забезпечуватися шляхом (КАС України містить вичерпний перелік): зупинення дії індивідуального акту чи нормативно-правового акту; заборони відповідачу вчиняти певні дії; заборони іншим особам вчиняти дії стосовно предмета спору; зупинення стягнення на підставі виконавчого документа / іншого документа, за яким стягнення здійснюється в безспірному порядку [10].

Про забезпечення позову або про відмову в цьому суд постановляє ухвалу, що обов'язково має містити мотиви, за яких суд дійшов висновку про необхідність застосування чи відмови вжиття заходів та зазначається вид забезпечення позову (ст. 154 КАС України) [10].

Вирішення питання про вжиття або невжиття заходів забезпечення позову за своєю правовою природою належить до дискреційних повноважень адмінсуду.

Поняття судової дискреції (розсуду) охоплює повноваження суду (права й обов'язки), надані йому державою, обирати між альтернативами, кожна 3 яких $\epsilon$ законною, та інтелектуальну-вольову владну діяльність щодо вирішення у визначених законом випадках спірних правових питань, виходячи із цілей та принципів права, загальних засад судочинства, конкретних обставин справи, принципів справедливості та верховенства права [11]. 
Дискреційні повноваження суду визнає і Європейський суд 3 прав людини (зокрема, рішення у справі «Довженко проти України»). У своїх рішеннях він наголошує лише на необхідності визначення законності, обсягу, способів і меж застосування свободи оцінювання представниками судових органів, виходячи із відповідності таких повноважень суду принципу верховенства права. Це забезпечується, зокрема, відповідним обгрунтуванням обраного рішення в процесуальному документі тощо.

Таким чином, адмінсуди мають певну свободу вибору в прийнятті рішення про необхідність забезпечення позову. Проте така свобода обмежена як загальними вимогами, що висуваються процесуальним законодавством до розгляду адміністративних справ та вимогами до судових рішень, так i спеціальними, що стосуються виключно інституту забезпечення позову.

Водночас, інститут забезпечення адміністративного позову $є$ однією 3 гарантій захисту прав, свобод та законних інтересів юридичних та фізичних осіб - позивачів в адміністративному процесі, механізмом, який покликаний забезпечити реальне та неухильне виконання судового рішення, прийнятого в адміністративній справі.

При цьому під час прийняття рішення про вжиття заходів забезпечення позову суди мають надати правильну правову оцінку підставам застосування цих заходів [12].

Водночас, проблема $\epsilon$ ще глибшою. Справа у тому, що зупинення дії нормативно-правового акту як захід забезпечення позову допускається лише у разі очевидних ознак протиправності такого акту та порушення прав, свобод або інтересів особи, яка звернулася до суду з позовом щодо такого акту.

Виникає питання, яким чином забезпечити позов, тобто зупинити дію нормативно-правового акту якщзо суду необхідно оџінити протиправність (встановити наявність цихх «очевидних ознак»), а че по суті можна зробити лише у рішенні по справі. Відповідно, суд не може оголосити свою правову позицію до винесення рішення у справі, демонструючи ставлення до питання забезпечення позову.

Іншим важливим питанням $є$ відсутність на рівні теорії та практики чітко розроблених схем зупинення нормативно-правових актів.

Для правильної та успішної реалізації приписів нормативно-правових актів важливо точно знати, з якого моменту починає діяти той чи інший акт і коли його дія припиняється. Саме в рамках цього хронологічного періоду приписи нормативно-правового акту підлягають обов’язковому виконанню.

Таким чином, стає очевидною необхідність удосконалення питання зупинення дії нормативно-правових актів із позицій теорії та практики правозастосування, що вимагає створення чіткого правового механізму зупинення дії нормативно-правового акту, через застосування інституційної системи Міністерства юстиції України та суб'єкта нормотворчості, нормативноправовий акт якого розглядається у межах певного адміністративного провадження.

Наслідки визнання нормативно-правового акта протиправним та нечинним можливо поділити на дві групи: матеріально-правові наслідки (щодо 
безпосереднього впливу на юридичну дію підзаконного нормативно-правового акту, що втрачає чинність повністю або в окремій його частині 3 моменту набрання законної сили відповідним рішенням суду) та процесуально-правові наслідки визнання нормативно-правового акта протиправним та нечинним визначені (позов про оскарження нормативно-правових актів, які відтворюють зміст або прийняті на виконання нормативно-правового акта, визнаного судом протиправним і нечинним повністю або в окремій його частині, розглядається судом за правилами спрощеного позовного провадження (ч. 3 ст. 265 КАС України).

Сам розгляд справи в порядку адміністративного судочинства виступає спеціальною правовою гарантією забезпечення режиму законності юрисдикційного характеру, що обумовлює пропозицію необхідності реагування нормотворчого органу на факт прийняття судового рішення щодо визнання нормативно-правового акту протиправним та нечинним. Зазначене може бути реалізоване через застосування такого інструменту, як «окрема ухвала».

Встановлена нами у процесі дослідження тенденція щодо фактичного невизнання втрати чинності підзаконного нормативно-правового акту на офіційних веб-сторінках, де здійснено розміщення їх тексту $\epsilon$ ще одним аргументом про необхідність розробки та прийняття нормативно-правового акту, який би регулював розробку та прийняття законодавчих актів в Україні.

Підкреслимо, що задоволення позовної заяви передбачає застосування з боку суду певного роду санкції щодо підзаконного нормативно-правового акту, який був предметом розгляду. Тобто, мова йде не лише про вирішення спору про право, а про застосування конкретних способів захисту порушеного права. Такою абсолютно-визначеною санкцією виступає «визнання протиправним та нечинним нормативно-правового акта чи окремих його положень» передбачена у п. 1 ч. 2 ст. 245 КАС України.

Сьогодні законодавство визначає нечинність підзаконного нормативноправового акту з моменту набрання сили прийнятого судового рішення. Про це йдеться у ч. 2 ст. 265 КАС України «Нормативно-правовий акт втрачає чинність повністю або в окремій його частині 3 моменту набрання законної сили відповідним рішенням суду». Водночас, це породжує проблему правових наслідків рішення щодо втрати чинності нормативно-правовим актом та питання зворотної дії у часі. Зазначена проблема вимагає свого науково-теоретичного опрацювання у майбутньому.

Висновки. Підсумовуючи наголосимо, що сьогодні вимагає свого удосконалення процес забезпечення позову у справах щодо оскарження підзаконних нормативно-правових актів. Для ефективності вирішення питання щодо застосування заходів забезпечення позову необхідно вирішити процесуальну «дилему»: як зупинити дію підзаконного нормативно-правого акту, якщо необхідно оцінити його протиправність (встановити наявність «очевидних ознак» протиправності), що по суті можна зробити лише у рішенні по справі. Відповідно, суд не може оголосити свою правову позицію до винесення рішення у справі, демонструючи ставлення до питання забезпечення позову.

3 метою ефективної реалізації забезпечення позову ми пропонуємо, 
здійснювати не зупинення дії підзаконного нормативно-правового акту в цілому, а лише у конкретних правовідносинах щодо особи, яка звернулася за захистом своїх інтересів шляхом оскарження нормативно-правового акту.

Залишається очевидною необхідність розробки питання зупинення дії нормативно-правових актів 3 позицій теорії та практики правозастосування, що вимагає створення чіткого правового механізму зупинення дії, через застосування інституційної системи Міністерства юстиції України та суб’єкта нормотворчості, нормативно-правовий акт якого розглядається у межах адміністративного провадження.

\section{Лimepamypa:}

1. Педько Ю.С. Становлення та правове регулювання адміністративної юстиції в Україні: автореф. дис... канд. юрид. наук: 12.00.07 : НАН України. Ін-т держави і права ім. В.М.Корецького. К., 2004. 16 с.

2. Грибок I.О. Оскарження рішень органів виконавчої влади в адміністративному порядку: автореф. дис... канд. юрид. наук: 12.00 .07 : НАН України. Ін-т держави і права ім. В.М.Корецького. К., 2006. 19 с.

3. Вовк П.В. Захист прав, свобод та інтересів громадян в адміністративному суді першої інстанції: автореф. дис... канд. юрид. наук: 12.00.07 : Одес. нац. юрид. акад. О., 2009. 22 с.

4. Калиновська Т. О. Нормативно-правові акти місцевих рад як органів місцевого самоврядування в Україні: автореф. дис. ... канд. юрид. наук : 12.00 .02 : Нац. акад. внутр. справ. К., 2011. 20 c.

5. Рябченко Я. С. Оскарження нормативно-правових актів в адміністративному судочинстві: автореф. дис. ... канд. юрид. наук : 12.00.07 : Юрид. акад. України ім. Ярослава Мудрого. Х., 2011. 19 с.

6. Кузьменко О.В. Адміністративний процес у парадигмі права : автореф. дис. д. ю. н. : 12.00 .07 ; Київський національний університет внутрішніх справ, Київ, 2006. 18 с.

7. Шевчук С. В. Судова правотворчість: світовий досвід і перспективи в Україні. Київ : Реферат, 2007. 264 с.

8. Блажівська Н. Процедура розгляду справ про оскарження нормативно-правових актів потребує вдосконалення. Вісник Вищого адміністративного суду Украӥни. 2009. № 1. С. 66-69.

9. Гетьман Є. А. Гетьман К. О. Порядок судового оскарження підзаконних нормативно-правових актів органів виконавчої влади. Теорія і практика правознавства. 2018. Вип. URL. http://nbuv.gov.ua/UJRN/tipp_2018_1_19. (дата звернення: 12.01. 2021).

10. Кодекс адміністративного судочинства України : Закон України від 6 липня 2005 року № 2747-IV. Верховна Рада України. База «Законодавство України». URL: https://zakon.rada.gov.ua/laws/show/2747-15\#n10618. (дата звернення: 12.01. 2021).

11. Кравцов I. Забезпечення позову в адміністративному процесі: вужчі можливості, більші труднощі. URL:https://zib.com.ua/ua/141770-zabezpechennya_pozovu_v_adminprocesi_ vuzhchi_mozhlivosti_bil.html (дата звернення: 12.01. 2021).

12. Верховний Суд роз'яснив, у яких випадках застосовуються заходи забезпечення позову. URL: https://dp.arbitr.gov.ua/archive/709973/ (дата звернення: 12.01. 2021).

\section{References:}

1. Ped'ko Ju.S. Stanovlennja ta pravove reguljuvannja administrativnoï justiciï v Ukraïni: avtoref. dis... kand. jurid. nauk: 12.00.07 : NAN Ukraïni. In-t derzhavi i prava im. V.M.Korec'kogo. K., 2004. $16 \mathrm{~s}$.

2. Gribok I.O. Oskarzhennja rishen' organiv vikonavchoï vladi v administrativnomu porjadku: avtoref. dis... kand. jurid. nauk: 12.00.07 : NAN Ukraïni. In-t derzhavi i prava im. V.M.Korec'kogo. K., 2006. 19 s. 
3. Vovk P.V. Zahist prav, svobod ta interesiv gromadjan $\mathrm{v}$ administrativnomu sudi pershoï instanciï: avtoref. dis... kand. jurid. nauk: 12.00.07 : Odes. nac. jurid. akad. O., 2009. 22 s.

4. Kalinovs'ka T. O. Normativno-pravovi akti miscevih rad jak organiv miscevogo samovrjaduvannja v Ukraïni: avtoref. dis. ... kand. jurid. nauk : 12.00 .02 : Nac. akad. vnutr. sprav. K., 2011. $20 \mathrm{~s}$.

5. Rjabchenko Ja. S. Oskarzhennja normativno-pravovih aktiv v administrativnomu sudochinstvi: avtoref. dis. ... kand. jurid. nauk : 12.00.07 : Jurid. akad. Ukraïni im. Jaroslava Mudrogo. H., 2011. $19 \mathrm{~s}$.

6. Kuz'menko O.V. Administrativnij proces u paradigmi prava : avtoref. dis. d. ju. n. : 12.00.07 ; Kiïvs'kij nacional'nij universitet vnutrishnih sprav, Kiïv, 2006. 18 s.

7. Shevchuk S. V. Sudova pravotvorchist': svitovij dosvid i perspektivi v Ukraïni. Kiïv : Referat, 2007. 264 s.

8. Blazhivs'ka N. Procedura rozgljadu sprav pro oskarzhennja normativno-pravovih aktiv potrebue vdoskonalennja. Visnik Vishhogo administrativnogo sudu Ukraïni. 2009. № 1. S. 66-69.

9. Get'man E. A. Get'man K. O. Porjadok sudovogo oskarzhennja pidzakonnih normativno-pravovih aktiv organiv vikonavchoï vladi. Teorija i praktika pravoznavstva. 2018. Vip. URL. http://nbuv.gov.ua/UJRN/tipp_2018_1_19. (data zvernennja: 12.01. 2021).

10. Kodeks administrativnogo sudochinstva Ukraïni : Zakon Ukraïni vid 6 lipnja 2005 roku № 2747-IV. Verhovna Rada Ukraïni. Baza «Zakonodavstvo Ukraïni». URL: https://zakon.rada.gov.ua/laws/show/2747-15\#n10618. (data zvernennja: 12.01. 2021).

11. Kravcov I. Zabezpechennja pozovu v administrativnomu procesi: vuzhchi mozhlivosti, bil'shi trudnoshhi. URL:https://zib.com.ua/ua/141770-zabezpechennya_pozovu_v_adminprocesi_ vuzhchi_mozhlivosti_bil.html (data zvernennja: 12.01.2021).

12. Verhovnij Sud roz'jasniv, u jakih vipadkah zastosovujut'sja zahodi zabezpechennja pozovu. URL: https://dp.arbitr.gov.ua/archive/709973/ (data zvernennja: 12.01. 2021). 